DOI:10.31696/2072-8271-2020-1-1-46-013-028

\title{
Achieving the Vision of the ASEAN Economic Community-2025: The Role of ASEAN Business Advisory Council
}

\section{Evgeny A. Kanaev}

Doctor of Historical Science, Professor, NRU HSE, Russia, Moscow, ekanaev@hse.ru,https://orcid.org/0000-0002-7988-4210

\section{Sofia M. Akhmanaeva}

CCEIS, NRU HSE, Russia, Moscow, smakhmanaeva@edu.hse.ru, https://orcid.org/0000-0003-4370-0747,

\section{Ekaterina A. Vaseneva}

NRU HSE, Russia, Moscow, eavasenyova@edu.hse.ru, https://orcid.org/ 0000-0002-7693-0736

Abstract: The paper analyses the role of ASEAN Business Advisory Council (ABAC) in stimulating transnational commercial exchanges in Southeast Asia as part of the establishment of the ASEAN Economic Community-2025. In like with this analytical focus, the authors start from revealing the specificity of the ASEAN Economic Community as a multilateral project tracing it from AEC-2015 to AEC-2025. The article argues that the role of the ABAC remains and will be defined by the overall evolution of ASEAN's modality of cooperation reflecting its potential and limitations.

Keywords: ASEAN Economic Community - 2025, scale effect, economic growth zones, legal connectivity, digital platforms, ASEAN Business Advisory Council

\section{Роль Делового Консультативного Совета АСЕАН в достижении целей экономического сообщества АСЕАН до 2025 года}

\section{Канаев Евгений Александрович}

доктор исторических наук, профессор НИУ ВШЭ, Россия, Москва, ekanaev@hse.ru, https://orcid.org/0000-0002-7988-4210

\section{Ахманаева София Михайловна}

НИУ ВШЭ, Россия, Москва, smakhmanaeva@edu.hse.ru, https://orcid.org/0000-0003-4370-0747

\section{Васенёва Екатерина Андреевна}

НИУ ВШЭ, Россия, Москва, eavasenyova@edu.hse.ru, https://orcid.org/0000-0002-7693-0736

Аннотация: В статье проанализирована роль ДКС АСЕАН в поощрении трансграничных коммерческих обменов в ЮВА в контексте формирования ЭС АСЕАН до 2025 г. Авторы приходят к выводу, что роль ДКС АСЕАН зависит и будет продолжать зависеть от общей

(C) Evgeny A. Kanaev, Sofia M. Akhmanaeva, Ekaterina A. Vaseneva, 2020. 
эволюции модальности сотрудничества АCEAH c eе потенциалом и ограничениями.

Ключевые слова: Экономическое Сообщество АСЕАН до 2025 года, эффект масштаба, зоны экономического роста, юридическая взаимосвязанность, цифровые платформы, Деловой Консультативный Совет ACEAH

The year 2020 marks the middle point between two ASEAN Economic Community (AEC) deadlines: the AEC-2015 and the AEC-2025. The final aim of the AEC project is to make Southeast Asia an area with economic scale effect. The task is not to outperform China as an economic powerhouse - suffice it to look at China's and ASEAN's populations and GDPs to see its futility. Nor is it to integrate ASEAN in the global economy - as practice demonstrates, global economic trends are more detrimental than conducive to ASEAN's long-term interests. The problem lies in a different dimension: along with the globalization of the Asia-Pacific region and Southeast Asia as its part, ASEAN is increasingly drifting in the contradictions between its extra-regional partners, mainly China and the United States, as a result of which the association may well fade into irrelevance.

To successfully respond to this challenge, the association has to achieve the scale effect. Specifically, this means to make Southeast Asia a unified economic and business-friendly area so as to stimulate domestic consumption and incentivize both ASEAN's and extra-regional companies to invest in Southeast Asia. Also, this includes stimulating transnational cooperation between the companies of the ASEAN memberstates from the substantial, legal, digital and institutional perspectives. In the latter regard, a timely exercise is to trace the activity and the interim results of ASEAN Business Advisory Council (ABAC).

$$
* * *
$$

\section{The ASEAN Economic Community Vision: from 2015 to 2025}

The ASEAN Economic Community, with all its flaws and deficiencies, remains the only one completed multilateral project of economic regionalism with declared eventual aims. With uncertain prospects of RCEP and CPTTP, as well as of APEC as a multilateral dialogue platform, the existence of AEC itself gives investors grounds for optimism. While assessing the specificity of the ASEAN Economic Community, the following factors bear relevance. 
First, the Association has always been overshadowed by its powerful neighbors. Suffice it to mention that since the establishment of ASEAN, the economic agenda of the ASEAN member states, as well as of the association as an international actor, has been defined by Japan (Singapore belonged to the NIE-1 while Malaysia, the Philippines, Thailand and Indonesia were members of the NIE-2 cohort). In the late 1980s - early 1990s, no less important was the influence of the US and Australia manifested by the establishment of APEC as an alternative platform of economic regionalism - even for ASEAN member states. Since the late 1990s, China's influence has been increasingly felt in Southeast Asia, later on strongly magnified by CAFTA and BRI. Lastly but importantly, South Korea and India have traditionally been ASEAN's principal economic partners.

Second, the association has been and remains torn apart by two mutually contradicting priorities. On the one hand, the ASEAN member states realize the necessity to achieve the scale effect since otherwise to counter the Chinese, American and Indian economic clouts is impossible. On the other hand, these countries have been unable to overcome the "curse of consensus" so that to perform this task. At present, this contradiction becomes more obvious as in the forthcoming digital era the scale effect increases its prominence in stimulating the B2B and the B2C exchanges.

Third, ASEAN understands that its competitiveness stems from the extent of regional connectivity. This has three dimensions: the physical connectivity, the institutional connectivity and the people-to-people connectivity. But in the present international circumstances, this narrative is seriously undermined. If so, efforts should be redoubled to stimulate exchanges at all levels as soon as the present COVID-19 pandemic goes down. But this will be difficult since at least two of the three connectivity pillars, by their very nature, require a constant increase of physical contacts.

The journey to the ASEAN Economic Community (as part of the ASEAN Community) started in 1997 when the association adopted ASEAN Vision 2020. The beginning of the 2000s gave the association new food for thought with relevance to the economic community building as Southeast Asia was losing its competitiveness vis-à-vis China and India. Additionally, bilateral FTAs between individual ASEAN member states and their extra-regional partners produced a dividing rather than an integrating effect on ASEAN's multilateral projects. The report issued by McKinsey revealed that the key reason for these disturbing 
trends stems from the fragmented state of ASEAN's market ${ }^{1}$. Consequently, the association realized it was imperative to ensure extraregional investors that Southeast Asia could become the unified area of economic and business activity.

After changing the date when the ASEAN Community was scheduled to be established from 2020 to 2015, the association issued the AEC Blueprint. In this document, the national, subregional, regional and global vectors of ASEAN community building efforts were outlined ${ }^{2}$. The final aim was to make Southeast Asia the unified investor-friendly geo-economic area in order to expand the instruments of ASEAN member states to re-energize their economic development.

Having implemented both interim scorecards and the final assessment of the ASEAN Economic Community, the association had to admit that the AEC was still work in progress. In fact, the process was not finalized as many problems remained unresolved. While the trade liberalization in the AFTA framework was successful, non-tariff barriers and infrastructure deficiencies undermined free flows of goods, services and investment. The priorities of multinationals which develop the East Asian value-added supply and production chains run counter to ASEAN's prospective plans since not all ASEAN member states participate in these networks. Of special note are remaining infrastructure gaps and significant differences in positions which the ASEAN member states occupy in global doing business rankings. But most importantly, ASEAN's principles of cooperation, including commercial disputesettlement mechanisms, were not modified since such attempts might have produced a dividing rather than an integrating effect on the intraASEAN multilateral projects.

At the same time, the strategic significance of AEC should not be underestimated. The fact that Southeast Asia is portrayed in the international media as a single market and a single production base itself incentivizes extra-regional multinationals to monitor business opportunities there ${ }^{3}$. The issues relevant to the global economy are often debated, which develops expertise on them in the ASEAN member states. This is all the more important since the Asia-Pacific region, as well as ASEAN and its institutions, is irreversibly globalizing.

To remedy the existing shortcomings and re-energize its community-building efforts, ASEAN adopted a new AEC vision (to 2025 as the target year). The new document, which includes five directions instead of four, is more result-oriented (as more deliberate cooperation is priori- 
tized) and more people-oriented (as the business community and civil society organizations are emphasized as stakeholders) ${ }^{4}$.

Summing up the main challenges the AEC-2025 is encountering, the following are worthy of note. The growing nationalism and protectionism, as aftereffects of incomplete national modernization, prioritize the implementation of national projects, while the regional cooperation still remains a secondary priority. China's economic pains strongly hit ASEAN and its prospective plans. The implications are manifold ranging from the dependence on China's slowdown when the PRC faces difficulties to economic and political blows as a result of China's pending rise. The middle development trap factor suggests that the ASEAN member states just do not expect too much from the AEC and participate in the AEC initiatives as long as it serves their interests. But most importantly, the current COVID-19 pandemic undermines the connectivity agenda as the key instrument and simultaneously goal of cooperation in order to make Southeast Asia an investor-attractive destination.

In the midst of the globalizing Asia-Pacific region and Southeast Asia as its part, which is reflected in the "Global ASEAN" as a direction of the AEC-2025, the association has to frame its response to the painful global realities.

Among the key challenges, the far-reaching aftereffects of the Fourth Industrial Revolution are especially worthy of note. To start, the "productivity paradox" matters since many technologically advanced software tools, like gaming and entertaining programs, do not aim to increase labor-based productivity while the beneficiaries of the free flows of information are mostly people with socially provocative behavior. As a consequence, the contradiction between income and qualification may well be constantly increasing. Concomitant with this development may well be prospects for the Southeast Asian countries to lose their hardwon competitive advantages.

Another likely aftereffect is the rise in inequality. From this perspective, Southeast Asia has always been a subregion of contrasts, but its present extent is really astonishing. As the ASEAN Post Team points out, "... The richest one percent in Thailand controls 58 percent of the country's wealth and the top 10 percent earned 35 times more than the bottom 10 percent. In Indonesia, the four richest men have more wealth than the poorest 100 million people, and about 50 percent of the country's wealth is in the hands of the top one percent. In Vietnam, 210 of the country's super-rich earn more than enough in a year to lift 3.2 mil- 
lion people out of poverty. The country's richest man earns more in a day than the poorest person earns in 10 years"

But the real problem stems from not the inequality per se, but from the implications it carries. Specifically, imbalances not only between, but also within (in both cases emphasis added - the authors) individual ASEAN member states may well be aggravated. Coupled with the ongoing rise of income inequality, this will exert destructive influence on the AEC. In the present context, an important factor should be mentioned: while in the "economic miracle" era the formation of the middle class was premised upon the advantage of time (since getting, for instance, vocational education and training usually takes several years), and the problem of inequality was more or less manageable, now obtaining new professional skills should be resolved within severe time constraints.

The present COVID-19 pandemic may well further exacerbate the problem of inequality due to aggravating social challenges in the Southeast Asian countries. A significant part of their population lives in slums with no medical care and social protection, not to mention overcrowded and unsanitary conditions. Other vulnerable segments include labor migrants, mostly in legal "grey zones", and the informal sector, as well as people living in remote rural areas. According to the available estimates, only four of ten ASEAN states have (near) universal health coverage ${ }^{6}$. If so, in the midst of the COVID-19 pandemic the deficiencies of social protection will remain grave regardless any implemented measures.

The aforesaid trends reveal the realistic assessment that the association and its member states have to expand the spectrum of their instruments to give their prospective plans a fresh impetus. At these complicated crossroads, ASEAN needs to allocate additional resources, mainly, the activity of the commercial sector of its member states, as the factor of economic growth and, by implication, economic regionalism.

\section{The Business Dimension of ASEAN's Economic Community Building Policy}

Stating that the necessity to integrate business in the AEC as a part of stimulating transnational exchanges (emphasis added) is growing, a preliminary remark is relevant. It is common knowledge that the ASEAN member states occupy different places in international rankings of doing business. It does not seem necessary to specifically point out that the percentage of, for instance, pave roads in Singapore differs from the corresponding indicators of, say, Laos, while the levels of protecting minority investors in Malaysia and Myanmar are not even remotely 
comparable. If so, the emphasis should be placed on the extent to which the business community of the ASEAN member states is ready to promote transnational exchanges. Since the implementation of this task is in itself time-consuming, the previously developed background is a vital precondition. At this analytical juncture, three contributory factors deserve exploring - the economic growth zones, the institutional and the digital aspects of transnational commercial exchanges.

In Southeast Asia, the economic growth zones focused on the transnational development of geographically close areas by means of jointly using production factors: goods, services, capital and manpower. The economic growth zones are based on the historically developed and consolidated ties, which in many cases are localized at trans-border areas rather than are integrated with other parts of the respective countries (for instance, the Indonesian islands Sulawesi and Sumatra are better linked with Malaysia rather than to Jakarta). The economic growth zones do not mean changing the trade policies of the countries involved, because of which to form a growth zone is easier and faster than to implement a fully-fledged integration initiative. The growth zones are nondiscriminatory against third countries: on the contrary, their output is focused primarily on third countries owing to shallow local markets and a narrow assortment of production. Lastly but importantly, these zones are often "public-private partnership testing grounds" in which the public sector tackles legal and administrative issues while the private sector is tasked mostly with project funding.

Examples of the development of the economic growth zones include the Greater Mekong Subregion Growth Zone, the Si-Jo-Ri Growth Zone (Singapore-Johor-Riau), BIMP-EAGA (Brunei - Indonesia - Malaysia - Philippines - East Asia Growth Area) and the IMT (IndonesiaMalaysia-Thailand) Growth Triangle. While details may differ, as the countries of, for instance, Si-Jo-Ri and the Greater Mekong Zone are hardly comparable in geography, levels of "hard" and "soft" infrastructure development, as well as in fundraising possibilities, their common feature is the down-top vector of cooperation, in which the private sector plays one of the pivotal roles.

But in practice, the private sector has been mostly reluctant, rather than enthusiastic, in developing these growth zones. In Singapore and Malaysia, mostly government-linked companies are provided with institutional and economic incentives ${ }^{7}$. There are not many large-scale projects in these zones; most of the business participation can be described as activities rather than projects ${ }^{8}$. 
The projects that require a large amount of investment are regarded by companies as too risky. Most of the enterprises are not ready to withstand domestic and regional competition simultaneously. The activities of foreign companies in some growth zones pose a risk for local producers, which discourages the private sector from active engagement.

From the institutional and the legal perspective, ASEAN's efforts to incentivize the companies of its member states to intensify their activity across Southeast Asia have produced mixed results. Although after shifting from AEC-2015 to AEC-2025, the association started to implement initiatives aimed at facilitating transnational economic exchanges, they still appear to be of limited practical use. Efforts to provide extraregional companies with information and facilitation support by developing the database ASEAN Trade Repository or the ASEAN Seamless Trade Facilitation Indicators, as well as launching the ASEAN Inclusive Business Framework, might have been timely steps, but for companies they remain a secondary, if not a low, priority until more pertinent questions are properly addressed ${ }^{9}$.

Among them, the key is lack of the ASEAN legal connectivity as an instrument to increase investors' confidence. In fact, not all ASEAN member-states have investment laws, while the countries that have such laws differ in their scope and functionality. For instance, while the Malaysian Promotion Investment Act focuses upon investment incentives, the Thai Foreign Business Act manly outlines investment conditions and sanctions in case of non-compliance. In the ASEAN member states, the investment laws are not synergized with the laws of general application. In some cases, more clarity on what kind of issues the investment law is to cover is needed - for instance, Myanmar's Special Economic Zone Law which does not contain the word "investment". More to the point, investment laws in the ASEAN member-states often differ from investment treaties. Specifically, an "umbrella clause" that imposes responsibilities on host countries and is found in investment treaties may well be missed in investment laws ${ }^{10}$.

Numerous regulatory requirements related but not limited corporate and "doing business" barriers, land and infrastructure use barriers, dispute settlement and contract enforcement issues etc. are still waiting for harmonization. This means mainly decreasing, or at least unifying, the complexity of doing business procedures and equity restrictions, but most importantly, the standardization of corporate legal systems all around the ASEAN member states. 
A nuanced understanding of the business perspective in the Southeast Asian context would be impossible without its digital dimension. The bottom line is that long-term success cannot do without the background developed in the pre-digital times. Actually, the association was unable to synergize its initiatives of economic regionalism with the demands of the Fourth Industrial Revolution. In the ASEAN context, the teething issues include, but are not limited to, legal aspects of trade in goods and services which become less distinguishable, taxation and social protection of employees involved in trans-border digital exchanges (especially relevant to the emerging production chains "Made in the Internet"), the balance between the informational openness and personal confidentiality. For the association, there are no examples to follow as the rules of multilateral cooperation, be it the General Agreement on Tariffs and Trade (GATT), the General Agreement on Trade in Services (GATS) or the Agreement on Trade-Related Aspects of Intellectual Property Rights (TRIPS) were formulated long before the present-day digital realities.

These issues should be seen in the right context: in Southeast Asia, a common market and a common production base still remain a wishful thinking rather than a fact of life. If so, business in Southeast Asia has to perform a double task, namely, to increase its efficiency in the previous conditions while simultaneously adopt to the new digital realities. Simultaneously, ASEAN is unlikely to define the digital agenda of cooperation within the framework of its multilateral economic initiatives including the Regional Comprehensive Economic Partnership, by means of providing the ASEAN member states and their companies with competitive advantages.

In the present COVID-19 circumstances, the enterprises of the ASEAN member states encounter serious difficulties. A revealing assessment points out that many of these enterprises use outdated ICT instruments, because of which to maintain sustainable remote working and well-organized digital customer channels is problematic. This inertia may take a long time to overcome ${ }^{11}$. A separate but closely related factor stems from lack of legal clarity of how the process of distant work is to be properly organized and maintained.

The potential of electronic retailers in Southeast Asia is weakened by the "last-mile delivery" problem and a large percentage of unbanked population. As of November 2019 , more than $70 \%$ of people in ASEAN were unbanked or underbanked, while most SMEs still accepted cash only $^{12}$. These problems existed before the present rise in demand for on- 
line orders in the conditions of the established quarantine, and now they have come in full force. This is not to mention a decrease in purchasing power of the population, as well as rising unemployment and increased pressure on employees so that to meet rocketing demand in buying products online ${ }^{13}$.

Simultaneously, Chinese electronic retailers increase their activity in Southeast Asia. Examples include the purchase of Lazada Group's controlling stake by Alibaba in 2016-2017, as well as interest of Tencent and Didi Chuxing to Grab and Go-Jerk. Previously, in 2014-2015 Alibaba bought $10.35 \%$ stake in Singapore Post and 34\% of its logistics service Quantium Solutions International ${ }^{14}$ while in 2018 it invested 1.1 billion dollars in Indonesian e-commerce platform Tokopedia. Another Chinese tech giant, Tencent, already owns a 35\% of Singapore based gaming and e-commerce SEA Group, which owns Shopee, the number one platform in Southeast Asia. In addition to its shares in Go-Jerk and Thai tech company Ookbee, Tencent's total investments in Southeast Asia account for 1.7 billion dollars. Also, JD.com has invested 0.6 billion dollars in the companies all over Southeast Asia, including the Vietnamese Tiki, the Thai Pomelo and Central Group, and the Indonesian Traveloka ${ }^{15}$.

This policy is strategically focused. At present, the Chinese electronic retailers aim to explore the $\mathrm{B} 2 \mathrm{C}$ (business-to-customer) sector. But conventional business logic suggests that sooner than later China will embrace the B2B (business-to-business) sector, in which switching costs for companies are incommensurably higher. As China becomes the only provider of both hard (physical) and soft (digital) infrastructure, it will realize the super-task of the digital part of the Belt and Road Initiative: setting the standards of digital cooperation in the industrial and the tertiary sectors.

This scenario seems plausible due to revealing developments in Southeast Asia during the COVID-19 pandemic. As of early May 2020, in the B2C sector consumer preferences were volatile with the focus mostly on FMCG goods at the expense of durables. Large retailers were better able to move online than small companies. Tellingly, in the B2B sector local on-line platforms could not effectively operate in the conditions of uncertainty. If so, the Chinese electronic retailers may well find it easy to penetrate the markets of Southeast Asian states further benefitting from the scale effect.

The afore-discussed developments suggest that problems the companies of the ASEAN member states are encountering are numerous and, 
in case left unattended, will multiply. Consequently, an additional instrument that can stimulate the transnational business exchanges from simultaneously substantial, institutional and digital perspectives is needed. In light of this, a good case to explore is the ASEAN Business Advisory Council.

\section{ASEAN Business Advisory Council: An Interim Assessment}

The ASEAN Business Advisory Council (ASEAN-BAC, ABAC) was established in 2003 to engage the private sector in the ASEAN Economic Community building process. Concerning the AEC-2025, the strategic objectives of the Council are to enable more effective participation of the private sector, including micro, small or medium-sized enterprises (MSMEs), in ASEAN's activities, and to support the implementation of sectoral projects ${ }^{16}$. Three main pillars of the Council's activity can be distinguished: (1) consulting states and business stakeholders, (2) coordinating its initiatives with ASEAN Secretariat and (3) engaging business enterprises in cooperation with each other and with ASEAN institutions, by means of this synergizing business and politics.

Specifically, the ABAC provides the political role players of the ASEAN member states with business analytics, as well as stimulates cooperation between business councils of individual ASEAN member states $^{17}$.

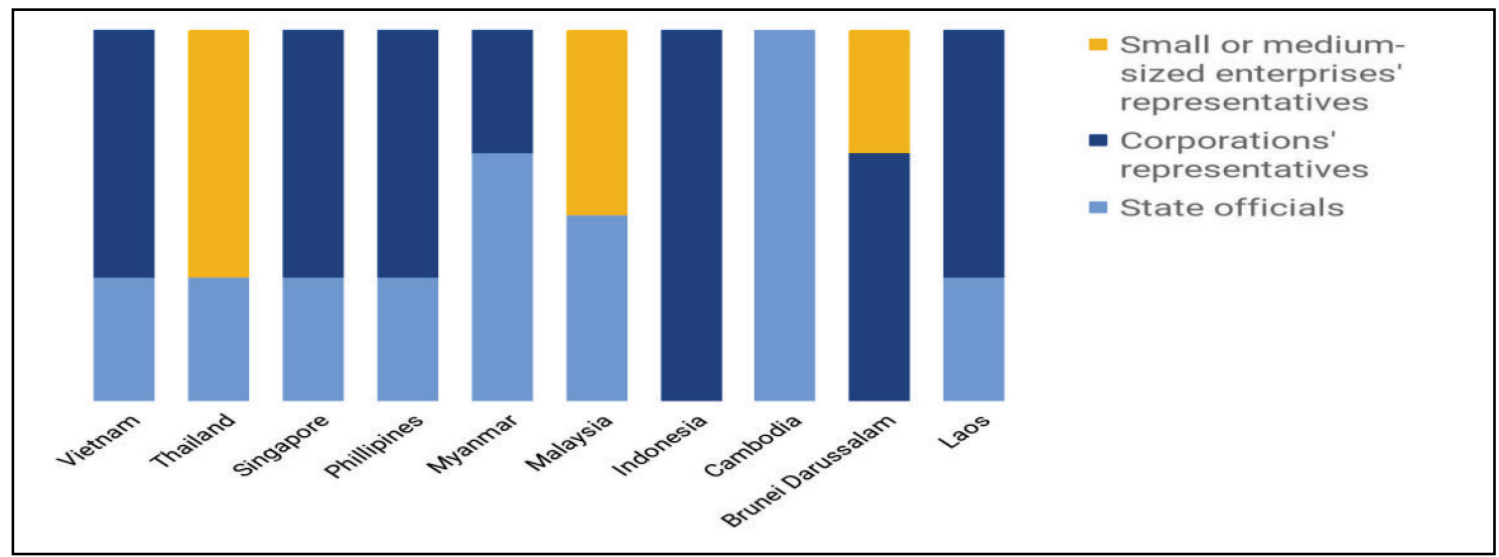

Table 1. ASEAN-BAC Members Per Country

Source: ASEAN Business Advisory Council Members // ASEAN Business Advisory Council [Electronic resource]. URL: https://www.asean-bac.org/members

Therefore, the membership of the Council reflects the interests of the private sector. ASEAN-BAC includes 3 representatives from each ASEAN member state, 30 in total, and is supposed to include CEOs of big and small or medium-sized enterprises (SMEs) ${ }^{18}$. During their man- 
date, they interact with both private sector representatives and state leaders, preparing reports for the governments. Although raising international competitiveness of SMEs is declared to be one of the primary objectives of the institution ${ }^{19}$, in practice, its members are mostly affiliated with large corporations.

The procedures of the interaction and consulting within the Council also reflect its vulnerabilities. Namely, meetings of the states' leaders and their representatives in the Council are usually conducted in a formal rather than a substantial way. Munir Majid, a former chairman of ASEAN-BAC, emphasizes that meetings are held in the form of reading statements and there is no room for discussion and exchange of ideas, not to say about making recommendations ${ }^{20}$.

The way the Council's activities are financed gives reasons for pessimism. The ad hoc principle prevails over the systematic member countries' funding contributions. Although, for instance, Malaysia and Laos raised allocations during their ASEAN chairmanships in 2015 and 2016 respectively, the lack of sustainable funding for implementing the ASEAN-BAC's projects is apparent ${ }^{21}$. For instance, the is no full-time paid Secretariat in the ASEAN-BAC.

Consequently, with respect to the Council's initiatives, they are not large-scale and mostly sporadic, although some of them can be considered effective. Specifically, the ASEAN Mentorship for Entrepreneurs Network (AMEN), the ASEAN Global Leadership Program (AGLP) and the ASEAN Business Awards (ABA) can be distinguished ${ }^{22}$.

Regarding the ASEAN Mentorship for Entrepreneurs Network, in May 2019, the Council held a pan-regional discussion on enhancing the global competitiveness of SMEs. Based on the Philippines' experience of the "Kapatid mentor-exercise program", the ASEAN-BAC launched this initiative to build the platform for mentorship and providing the SMEs with expertise. Besides, the ASEAN-BAC has also engaged Japan in funding the AMEN: the Japan-ASEAN Integration Fund (JAIF) contributed approximately 347,000 dollars $^{23}$. While the scale of the project is quite modest, the positive impact of the Council here is undeniable.

The ASEAN Global Leadership Program has been held annually since 2009. The program provides its members with the Fellowship grant and good instruments to cooperate with top universities (Berkeley, LSE, Cheung Kong Graduate of Business etc. $)^{24}$. In 2019, seven scholars received the scholarship to participate in the AGLP educational program $^{25}$. Thus, the project, like the previous one, focuses on the qualitative development of human capital and enhancing the private sector 
competitiveness, rather than on the quantitative side of cooperation by increasing the number of initiatives and participants.

As an exception, the ASEAN Business and Investment Summit (ABIS) is the platform for the realization of the Council's goals, namely, developing the AEC and engaging the private sector in policymaking. The ABIS is held annually and gathers about a thousand participants, including high-level state officials and top businessmen ${ }^{26}$. The agenda of the Summit encompasses the issues of trade liberalization, digitalization, the development of human capital and MSMEs. During the Summit, its participants have an opportunity to discuss policy issues simultaneously broadening their networks of professional contacts.

The ASEAN Business Awards (ABA) was launched in 2007 to encourage the private sector contribution to ASEAN's activities ${ }^{27}$. In 2019, the Skills Development Award was established to bolster the development of human resources and a system of technical and vocational education and training (TVET) in Southeast Asia. This award is supported by the German government and a German enterprise "Gesellschaft für internationale Zusammenarbeit" (GIZ) ${ }^{28}$. These activities encourage the ASEAN community building process, as well as strengthen links ASEAN companies and multinationals. This follows the AEC-2025 logic, which is exemplified by, for instance, paragraph 10.4 of the ASEAN Community Vision to 2025 about an inclusive, people-oriented and people-centered community ${ }^{29}$.

Concerning cooperation with institutions with a similar profile, the Council collaborates with EU-ASEAN Business Council and U.S.ASEAN Business Council. Although they prepare joint statements and reports, there is no apparent practical impact of such collaboration ${ }^{30}$.

To conclude, the ASEAN Business Advisory Council does not have enough capabilities to become the primary institution of interaction and coordination between companies, as it initially was supposed to be. The membership, proceedings and initiatives of the ASEAN-BAC reveal that due to lack of resources, this body cannot achieve the implementation of its strategic objectives. In terms of consulting, the procedural mechanisms do not facilitate discussion to influence upon the AEC implementation. The ABAC remains a platform where business and professional contacts are established and maintained, which is likely to continue in the years to come.

\section{Conclusion}

The undertaken assessment of the role of the ABAC in stimulating transnational business exchanges in Southeast Asia from the viewpoint 
of the ASEAN Economic Community to 2025 reveals several conclusions.

As compared to the AEC-2015, the road to the AEC-25 has become more difficult. The ASEAN member states have been unable to achieve the scale effect as Southeast Asia is still a fragmented rather than unified economic area. Infrastructure deficiencies coupled with the turn to protectionism as a conspicuous global and regional trend overlap with the aftereffects of the Fourth Industrial Revolution from which the association is unlikely to benefit. The COVID-19 pandemic multipliers the challenges ASEAN is encountering, mostly from the inequality perspective.

As the region recovers from the COVID-19, the business activity in Southeast Asia will naturally decrease. The expected inward focus of the ASEAN member states will discourage the development of the connectivity agenda in the intra-ASEAN cooperation. Coupled with a decrease in incomes in most of the ASEAN member states, this will undermine transnational business exchanges as a precondition for realizing the goals of AEC-2025.

In its turn, business alone has been unable to undertake the initiative in strengthening the down-top vector of ASEAN's efforts. The growth zones turned out to be of limited interest to business while from the legal and the digital perspectives much remains to be done to make transnational commercial exchanges sustainable. This makes it relatively easy for China's companies to operate in Southeast Asia to China's best advantage.

The contribution of the ASEAN Business Advisory Council in stimulating transnational business exchanges in Southeast Asia has been limited at best. In fact, ABAC's role is limited to providing a platform for dialogue rather than shaping it. Responding to the logic of the ASEAN cooperation, ABAC's functionality reflects the evolution of ASEAN as a multilateral dialogue platform. If so, changes are likely to mirror the evolution of ASEAN with its potential and limitations.

\footnotetext{
${ }^{1}$ This issue is elaborated in: (2005) Roadmap to an ASEAN Economic Community. Ed. by Hew Dwi-Yen D. Singapore, ISEAS.

${ }^{2}$ ASEAN Economic Community Blueprint // ASEAN. 2008. URL: https://asean.org/wpcontent/uploads/archive/5187-10.pdf

${ }^{3}$ Basu Das S. The ASEAN Economic Community: An Economic and Strategic Project // ISEAS perspective. 2015. №4. URL: https://think-asia.org/bitstream/handle/11540/ 10984/ISEAS_Perspective_2015_4.pdf?sequence=1
} 
${ }^{4}$ ASEAN Economic Community Blueprint 2025 // ASEAN. 2015. URL: https://www.asean.org/storage/2016/03/AECBP_2025r_FINAL.pdf

${ }^{5}$ Southeast Asia's Widening Inequalities // The ASEAN Post. 2018. URL: //

https://theaseanpost.com/article/southeast-asias-widening-inequalities

${ }^{6}$ Lee C. C. The Coronavirus Crisis Is Laying Bare Southeast Asia's Inequality Problem // The Diplomat. 2020. URL: https://thediplomat.com/2020/04/the-coronavirus-crisis-islaying-bare-southeast-asias-inequality-problem/

7 ASEAN Investment Report 2017 // UNCTAD. 2017. URL: https://unctad.org/en/ PublicationsLibrary/unctad_asean_air2017d1.pdf

${ }^{8}$ Mid-Term Review of the Indonesia-Malaysia-Thailand Growth Triangle (IMT-GT)

Roadmap for Development: 2007-2011 // ADB. 2010. URL: https://www.adb.org/ publications/mid-term-review-indonesia-malaysia-thailand-growth-triangle-imt-gtroadmap-development

${ }^{9}$ For more detailed information, see a series of ASEAN Economic Integration Brief, №1-6

- ASEAN Economic Integration Brief // ASEAN. URL: // https://asean.org/aseaneconomic-community/aec-monitoring/asean-economic-integration-brief/

${ }^{10}$ Investment Laws of ASEAN Countries: A Comparative Review // IISD Report. 2017.

URL: https://www.iisd.org/sites/default/files/publications/investment-laws-aseancountries.pdf

${ }^{11}$ Izwan I. Covid-19 Drives Digital Transformation for ASEAN Enterprises // The New Straits Times. 2020. URL: // https://www.nst.com.my/lifestyle/bots/2020/05/590324/techcovid-19-drives-digital-transformation-asean-enterprises

${ }^{12}$ Fulfilling Its Promises. The Future of Southeast Asia's Digital Financial Services // Bain \& Company. 2019. URL: http://think.storage.googleapis.com/docs/future-of-southeastasia-digital-financial-services.pdf

${ }^{13}$ Yatid M., Chua R. No Easy Roads to Take Even for E-Commerce Amid COVID-19 // The Khmer Times. 2020. URL: https://www.khmertimeskh.com/50720696/no-easy-roadsto-take-even-for-e-commerce-amid-covid-19/

${ }^{14}$ China Tech Giants to Fight for \$53B SEA E-commerce Market // ZDnet. 2018. URL: https://www.zdnet.com/article/china-tech-giants-to-fight-for-53b-sea-e-commerce-market/ ${ }^{15}$ Tencent Looks to Counter China Freeze with Sea Deal // Financial Times. URL: https://www.ft.com/content/c995972e-ebb4-11e8-89c8-d36339d835c0

${ }^{16}$ ASEAN Economic Community Blueprint 2025 // ASEAN. 2015. URL: https://www.asean.org/storage/2016/03/AECBP 2025r_FINAL.pdf

${ }^{17}$ ASEAN Economic Community Blueprint $2025 \ldots$

${ }^{18}$ ASEAN Business Advisory Council Members // ASEAN Business Advisory Council. URL: https://www.asean-bac.org/members

${ }^{19}$ ASEAN Leaders Express Keen Interest in Promoting SMEs: ABAC // Atuc. 2015. URL: http://aseantuc.org/2015/04/2742015-asean-leaders-express-keen-interest-in-promotingsmes-abac/

${ }^{20}$ Munir M. Forging the ASEAN Economic Community, 2015 To 2016 - and Beyond // Southeast Asian Affairs. 2017. Vol. 2017. P. 43-53.

${ }^{21}$ Munir M. Forging the ASEAN Economic Community, 2015 To 2016 - and Beyond...

${ }^{22}$ ASEAN Global Leadership Program (AGLP) // ASEAN Business Advisory Council.

URL: https:/www.asean-bac.org/news/show/92-2019-asean-global-leadership-programaglp-fellowship

${ }^{23}$ AMEN Regional Discussion on the ASEAN Mentorship for MSMEs and Training Framework // ASEAN Business Advisory Council. URL: https://www.asean- 
bac.org/news/show/86-amen-regional-discussion-on-the-asean-mentorship-for-msmes-andtraining-framework\#

${ }^{24}$ ASEAN Global Leadership Program (AGLP) // ASEAN Business Advisory Council. URL: https:/www.asean-bac.org/news/show/92-2019-asean-global-leadership-programaglp-fellowship

${ }^{25}$ SRW\&Co. Announces ASEAN Global Leadership Program Scholars // ASEAN Business Advisory Council. 2019. URL: https://www.asean-bac.org/news/show/81-srwcoannounces-asean-global-leadership-program-scholars

${ }^{26}$ ASEAN Business and Investment Summit (ABIS) // ASEAN Business Advisory Council. 2019. URL: https://www.aseanbac2019.org/activity/view/40

${ }^{27}$ ASEAN Business Awards 2019 // SEA-VET.NET. 2019. URL: https://sea-

vet.net/initiatives/518-asean-asean-business-awards-2019-call-for-nominations-for-skillsdevelopment-award

${ }^{28}$ First Companies Recognized in New Skills Development Category of The Prestigious ASEAN Business Award // SEA-VET.net. 2019. URL: https://sea-vet.net/news/613-firstcompanies-recognized-in-new-skills-development-category-of-the-prestigious-aseanbusiness-award

${ }^{29}$ ASEAN Community Vision 2025 // ASEAN. 2015. URL: https://www.asean.org/wpcontent/uploads/images/2015/November/aec-page/ASEAN-Community-Vision-2025.pdf ${ }^{30}$ Press Statement: EU-ASEAN Business Council and ASEAN Business Advisory Council Launch Report on Non-Tariff Barriers in ASEAN: Both Bodies Call for Faster Action on Removal of NTBS // ASEAN Business Advisory Council. 2019. URL: https://www.aseanbac.org/news/show/90-press-statement-eu-asean-business-council-and-asean-businessadvisory-council-launch-report-on-non-tariff-barriers-in-asean-both-bodies-call-for-fasteraction-on-removal-of-ntbs

The article is the outcome of the HSE project Institutions of Multilateral Cooperation in the Asia-Pacific Region: the Business Dimension

Статья поступила в редакцию 11.05.2020, принята к публикации 20.05.2020. 